\title{
PUBLIC GOVERNMENT OF EDUCATION FOR HUMAN CAPITAL DEVELOPMENT: CASE OF EUROPE AND UKRAINE
}

\author{
Myroslava Olievska ${ }^{1}$, Sergii Petrukha ${ }^{2}$ \\ ${ }^{1}$ PhD (Economics), Associate Professor, International University of Economics and Humanities named after \\ Stepan Demianchuk,e-mail: 3mad@ukr.net,ORCID: https://orcid.org/0000-0001-8818-0509 \\ ${ }^{2} \mathrm{PhD}$ (Economics), Associate Professor, «KROK» University, Kyiv, Ukraine, e-mail: \\ psv03051984@gmail.com, ORCID: https://orcid.org/0000-0002-8859-0724
}

Education is the tool which provides people require knowledge, skill, technique, and information and enables them to know their rights and duties. Education develops the human capital, and creates more productive impacts upon the future generation. By providing education, governments remove the poverty and every person in the country will become successful and provides their contribution to developing their country.

Human capital consists of the knowledge, skills, and health that people accumulate over their lives. People's health and education have undeniable intrinsic value, and human capital also enables people to realize their potential as productive members of society. More human capital is associated with higher earnings for people, higher income for countries, and stronger cohesion in societies. It is a central driver of sustainable growth and poverty reduction (World Bank, 2020).

So, for an evolution of a country, there is need of education, and in a modern society, education should be available and universal, democratic in method, and reliant on well-trained professional teachers. In accordance in all countries educational reforms designed to assure access at the lowest level for all citizens and state support at the higher levels for the most talented. Governments is committed to improving public outcomes through a focus on people and in such sectors as the military, law enforcement, infrastructure, public transit, education, health care and others. In particular, the main means of influencing education and training in all countries are public government and financing. The government expenditure on education determines the development of the labor market, human capital development, income, standard and quality of life. However, the mechanisms and instruments for financing education and training in the EU and in Ukraine are significantly different.

The work aims to highlight the advantages of financing education in EU for quality improvement of education in Ukraine.

The main conclusions of the work were developed through a meaningful analysis of scientific papers, documents and statistical reports of international organizations and the European Union about financing of education for sustainable development of human capital. 
The research is based on the methods of statistical analysis (based on EU Member States data on distribution of expenditure on education, public expenditure on education relative to GDP was determined), the tabular and graphical method for visual display of the received data. In addition, the authors used the findings of their previous research in the field of education and human capital development.

The role of government in education. Education is important for all societies and at different times.

In his 1955 article, "The Role of Government in Education" Friedman defined the reason for government involvement in any economic activity, and identified three special cases where government involvement is justified: the presence of a monopoly; neighborhood effects; and paternalism (who should make the educational choices for children).

Friedman theorized that a stable and democratic society is impossible without widespread acceptance of some common set of values and without a minimum degree of literacy and knowledge on the part of most citizens. Education contributes to both. In consequence, the gain from the education of a child accrues not only to the child or to his parents but to other members of the society; the education of one child contributes to other people's welfare by promoting a stable and democratic society (Friedman, 1955).

Today quality education allows human capital development and promoting the Sustainable Development. According to experts, education yields in both the private and public sector in terms of learning and higher learning more so, it benefits the society in social ways (Friedman, 2015; Landry et al, 2016). That is why the main priority of governments is provide the right to access safe, quality education; it is essential for the governments to invest in education since it yields progressive externalities.

In this context, it is necessary to rethink the role of education in the development of society, and the achievement of economic growth.

Both national and European experts agree that the role of governments in education is as follows:

1. Providing equality in education. The government ensures that the public schools offer a high quality of knowledge to the learners.

2. Funding education. The governments must actively fund education and training, because education fights poverty in the nation and the society. Therefore to eliminate poverty the government has to eradicate illiteracy among its people, and significantly investing in future. Free education could help the needy people, and increases the literacy level in the country thus human capital development.

3. Provision of meals in schools by the government. 
4. The governments can subsidize education in several forms such as school fees for low-income parents, lower school fees et al. In all countries the private schools has always given competition to public school by acquiring high grades in their examinations thus attracting more investors in their business compared to the public (Horn and Paslov, 2014). But private schooling can be remained out of reach for the majority since the private sector is driven by the profit gains thus exploiting parents.

5. A government should ensure teachers are well paid so that they are motivated in the provision of their services - the salary of teachers is proportional to their work

6. A government should put in place rules that could check to eliminate outdated syllabus since it misdirects many teachers and learners in schools (Friedman, 2015). Effective syllabus acts as a tool for excellent performance in schools since the teacher teaches what is tested nationally. Learners could be able to compete with other students elsewhere since they are subjected to the same thing and if the comparison can be made, it will be fair to all the learners.

7. A government should ensure that private institutions interested in carrying out educational activities meet certain standards. Private sectors mostly run for profit gains and not what they are licensed to do.

8. A government should act towards empowering school leaders and teachers towards professional responsibility and set standards and support them wholly in a quest to deliver quality learning prospects for the learners. Teachers need to be trained so that they can manage well in the school setting. Since without qualifying one is regarded as not restricted, therefore, he or she cannot take roles to lead or teach students (Friedman, 2015).

9. The government should establish training centers to cater for teachers training. Presence of training centers could motivate teachers to even further their educations to the higher level, and after that be able to give back to the community as qualified personnel.

However in 2020, scientists began to think that the public sector should not be responsible for all aspects of education in both developed and developing countries. James Tooley (2020) calls four main reasons:

- there are doubts about the effectiveness and efficiency of public education;

- there are doubts about the equity and accountability of public education, which particularly affect the poor;

- there is an increasing awareness of initiatives by educational entrepreneurs, and evidence to suggest that competitive pressures can lead to significant educational improvements; 
- There has been a need to restrain public expenditure in order to reduce budget deficits and external debts, and, consequently, a need to find alternative sources of educational funding (Government and Education, the Changing Role of, 2020).

Yet in times of epidemics, conflict and disaster fundamental right of education is often significantly disrupted, denying millions of girls and boys the opportunity to have a quality, safe education. And here we must agree with the opinion of experts that, states should support education and human capital development in crisis times.

According to The Human Capital Index 2020 Update: Human Capital in the Time of COVID-19 (World Bank, 2020), the COVID-19 pandemic threatens to reverse many of gains, which countries have made in improving human capital over the past decade. Urgent action is needed to protect hard-won advances in human capital, particularly among the poor vulnerable. Designing the needed interventions of governments, targeting them to achieve the highest effectiveness, and navigating difficult trade-offs in times of reduced fiscal space, makes investing in better measurement of human capital more important than ever. Experts expressed, that school closures combined with family hardship are significantly affecting the accumulation of human capital for the current generation of school-age children (World Bank, 2020).

\section{The European experience of public government and financing of education.} In European Union primary responsibility for education and training policies lies with the Member States, with the European Union functioning in a solely supporting role, such as to shall contribute to the development of quality education by encouraging cooperation between Member States and, if necessary, by supporting and supplementing their action, while fully respecting the responsibility of the Member States for the content of teaching and the organization of education systems and their cultural and linguistic diversity. In defining and implementing its policies and activities, the Union shall take into account requirements linked to the promotion of a high level of employment, the guarantee of adequate social protection, the fight against social exclusion, and a high level of education, training and protection of human health. The EU's long-term strategic objectives on education and training as set out in the Council Conclusions of 12 May 2009 are:

-Making lifelong learning and mobility a reality;

-Improving the quality and efficiency of education and training;

-Promoting equity, social cohesion and active citizenship;

-Enhancing creativity and innovation, including entrepreneurship, at all levels of education and training (Education and Vocational Training).

Key features of public government in education in EU Member States: 
1. Vocational training was identified as an area of Community action in the Treaty of Rome in 1957; education was formally recognized as an area of EU competence in the Maastricht Treaty in 1992; the Treaty of Lisbon retained the provisions on the role of the EU in education and training.

2. In the twenty-seven EU Member States, education is mainly funded by governments, private sources (households, enterprises, non-profit organizations and religious institutions), international organizations (United Nations, World Bank).

Given that, expenditures on education may help foster economic growth, enhance productivity, contribute to people's personal and social development, and help reduce social inequalities (Educational expenditure statistics), EU Member States actively fund education and training. In particular:

According to Education expenditure statistics (Table 1), the highest overall levels of government expenditure on education were in Germany (EUR 140.8 billion), in France (EUR 121.1 billion), that is, in the most populous EU Member States. Government expenditure on education was significantly lower in Italy (EUR 64.7 billion) and Spain (EUR 45.6 billion).

In 2012-2016 the highest rates of increase for government expenditure on education were in Bulgaria, Hungary, and Malta; the level of government expenditure on education fell in six of the Member States (Italy, Czech, Lithuania, Slovenia, Cyprus, and Latvia).

Government expenditure account $74-98 \%$ of all education expenditures (including payments and transfers for education to the non-educational private sector - this includes subsidies to households and students as well as payments to other noneducational private entities) in different Member States. Private sources covered about $14 \%$ of total education spending, but $20-25 \%$ in Slovakia, Bulgaria, Portugal, Spain, and Cyprus.

Contribution of international organizations - 1-3\%; Lithuania (3.1\%) and Portugal (3.0\%) received the most from international organizations for education and training (Table 1).

One third of all resources were used to finance higher education, although there were six exceptions among the EU Member States: Hungary, Luxembourg, Italy, Belgium, Cyprus and Portugal. The remaining financial resources were unevenly distributed among other levels of education. At the same time, a significant share in the structure of total expenditures on education and training is occupied by expenditures on the secondary education system, as they depend on the number of years of study and the number of pupils / students. 


\section{Table 1. Distribution of expenditure on education (excluding early childhood educational development) by sector in the $\mathrm{EU}$}

\begin{tabular}{|c|c|c|c|c|c|c|c|c|c|}
\hline \multirow[t]{2}{*}{ Country $^{1}$} & \multicolumn{3}{|c|}{$\begin{array}{l}\text { Sector, } \% \text { of combined public, } \\
\text { private and international } \\
\text { expenditure on education }\end{array}$} & \multicolumn{2}{|c|}{$\begin{array}{l}\text { Public expenditure on } \\
\text { education (excluding } \\
\text { early childhood } \\
\text { educational } \\
\text { development), } 2016\end{array}$} & \multicolumn{2}{|c|}{ Real GDP per capita } & \multicolumn{2}{|c|}{$\begin{array}{l}\text { The Human } \\
\text { Capital Index }\end{array}$} \\
\hline & $\begin{array}{l}\text { Gover } \\
\text { nment }\end{array}$ & $\begin{array}{c}\text { Non- } \\
\text { educatio } \\
\text { nal } \\
\text { private }\end{array}$ & $\begin{array}{l}\text { Internati } \\
\text { onal } \\
\text { organiza } \\
\text { tions }\end{array}$ & $\begin{array}{l}\text { Million } \\
\text { EUR }\end{array}$ & $\begin{array}{l}\text { Expenditure } \\
\text { relative to } \\
\text { GDP, \% }\end{array}$ & 2016 & 2019 & Score & Rank \\
\hline \multicolumn{10}{|c|}{ Countries with large real GDP per capita } \\
\hline Luxembourg & 92.5 & 4.7 & 2.8 & 1912.4 & 3.6 & 82880 & 83640 & 0.69 & 40 \\
\hline Ireland $^{3}$ & 90.5 & 8.8 & 0.7 & 9878.1 & 3.8 & 50710 & 60350 & 0.81 & 6 \\
\hline Denmark & $:$ & $:$ & $:$ & : & $:$ & 46720 & 49180 & 0.77 & 17 \\
\hline \multicolumn{10}{|c|}{ Countries with medium real GDP per capita } \\
\hline Sweden $^{3}$ & 95.7 & 3.4 & 1.0 & 33012.2 & 7.1 & 42920 & 43840 & 0.80 & 10 \\
\hline Netherlands & 81.9 & 17.2 & 0.9 & 38814.0 & 5.5 & 39810 & 41870 & 0.80 & 9 \\
\hline Austria $^{2}$ & 93.7 & 6.3 & 0.0 & 19234.7 & 5,4 & 36430 & 38250 & 0.79 & 11 \\
\hline Finland & 93.5 & 5.5 & 1.0 & 14159.4 & 6.6 & 35320 & 37270 & 0.81 & 5 \\
\hline Germany & 83.3 & 16.3 & 0.4 & 140750 & 4.5 & 34700 & 35980 & 0.79 & 12 \\
\hline Belgium & 89.1 & 9.8 & $1 ., 1$ & 27229.2 & 6.4 & 34690 & 35900 & 0.76 & 22 \\
\hline France $^{2}$ & 86.1 & 13.4 & 0.5 & 121069 & 5.4 & 31770 & 33270 & 0.76 & 23 \\
\hline \multicolumn{10}{|c|}{ Countries with small real GDP per capita } \\
\hline Italy & 81.4 & 17.7 & 0.8 & 64707.7 & 3.8 & 26020 & 26860 & 0.77 & 18 \\
\hline Spain $^{2}$ & 76.3 & 23.3 & 0.4 & 45634.9 & 4.1 & 23760 & 25170 & 0.74 & 33 \\
\hline Cyprus $^{2}$ & 74.4 & 24.7 & 0.9 & 1113.8 & 6.0 & 22360 & 24250 & 0.75 & 28 \\
\hline Malta & 83.5 & 16.5 & 0.1 & 496.7 & 4.8 & 20260 & 22040 & 0.70 & 39 \\
\hline Slovenia $^{2}$ & 83.8 & 14.2 & 2.0 & 1819.8 & 4.5 & 18540 & 20490 & 0.79 & 13 \\
\hline Greece & $:$ & $:$ & $:$ & 6458.0 & 4.0 & 17110 & 18150 & 0.68 & 43 \\
\hline Portugal & 76.2 & 20.8 & 3.0 & 8745.4 & 4.7 & 17010 & 18540 & 0.78 & 15 \\
\hline Czechia & 85.5 & 13.7 & 0.9 & 6280.9 & 3.6 & 16520 & 18000 & 0.78 & 14 \\
\hline Slovakia & 78.1 & 20.0 & 1.9 & 3156.3 & 3.9 & 14550 & 15890 & 0.69 & 41 \\
\hline Estonia & : & : & : & 916.0 & 5.0 & 13650 & 15670 & 0.75 & 29 \\
\hline Lithuania & 82.9 & 14.0 & 3.1 & 1508.6 & 3.9 & 12040 & 13880 & 0.71 & 37 \\
\hline Hungary $^{2}$ & 85.0 & 15.0 & 0.0 & 5080.3 & 4.5 & 11410 & 13180 & 0.70 & 38 \\
\hline Poland & 83.5 & 14.8 & 1.7 & 19788.9 & 4.6 & 11260 & 12980 & 0.75 & 31 \\
\hline Croatia & $:$ & $:$ & $:$ & $:$ & $:$ & 11100 & 12480 & 0.72 & 35 \\
\hline Latvia & 83.3 & 13.9 & 2.8 & 1181.7 & 4.7 & 11030 & 12490 & 0.72 & 36 \\
\hline Romania & 97.8 & 1.1 & 1.1 & 4393.9 & 2.6 & 7720 & 9130 & 0.60 & 67 \\
\hline Bulgaria & 77.1 & 20.5 & 2.5 & 1859.6 & 3.9 & 6050 & 6800 & 0.68 & 42 \\
\hline
\end{tabular}

Source: Calculated based on (Educational expenditure statistics; The World Bank).

The highest government expenditure on education relative to GDP among the EU Member States was in Sweden (7.1\%) and Finland (6.6\%). 


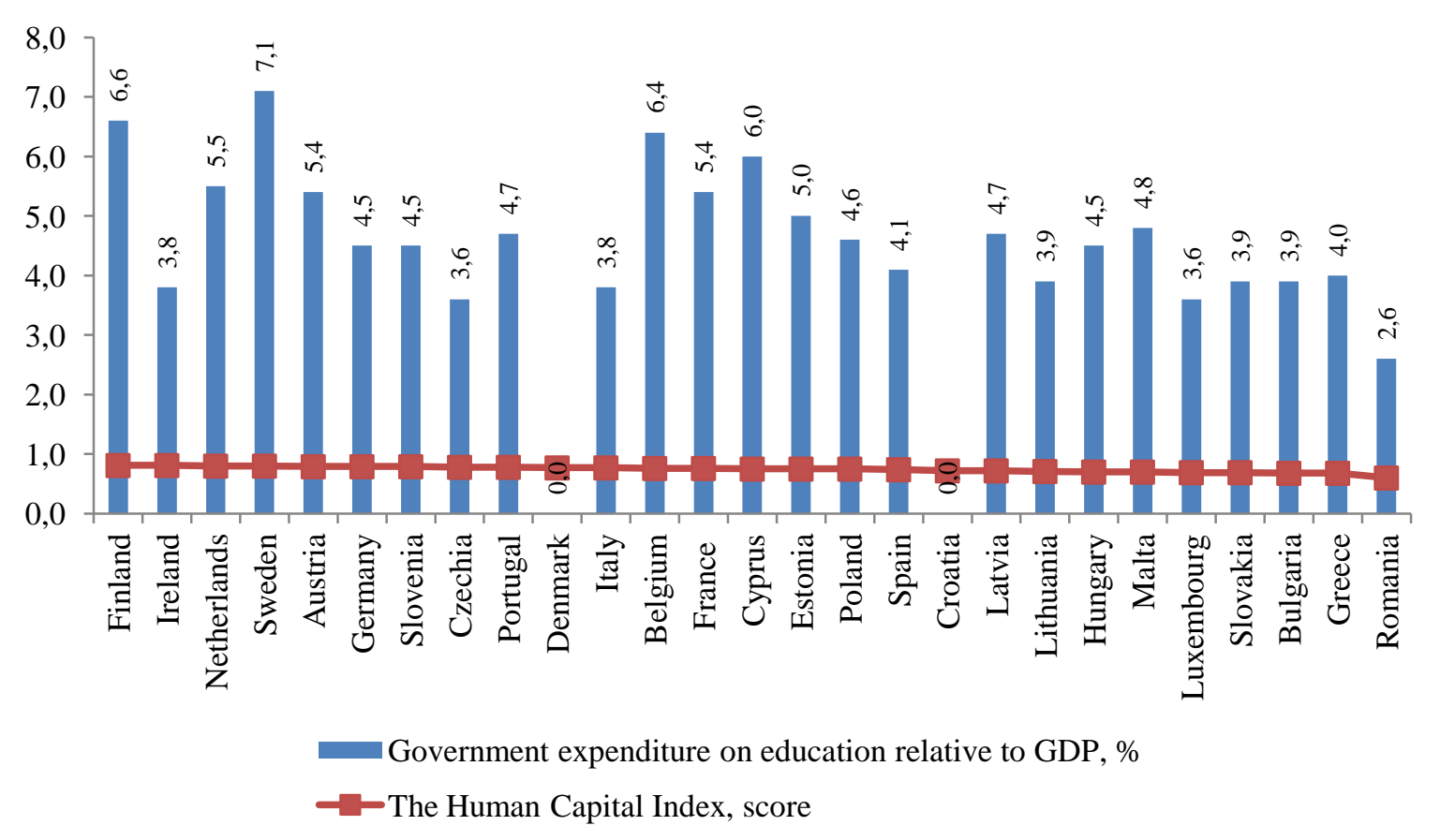

Fig. 1. The relationship between government expenditure on education relative to GDP and the Human Capital Index

Source: Educational expenditure statistics; The World Bank

All the EU Member States have a value of human capital in the rating of The Human Capital Index from 0.6 to 0.81 points (while 1 point indicates a high level contribution of education and health care to the productivity of the next generation of workers and thus account the risks of poor health and poor education. But the number of points and place in the ranking do not depend on government expenditure on education. It is obvious that the development of human capital is also influenced by such factors as the efficiency of use of funds, financing by other sectors, organizational aspects, etc.

In addition to the Human Capital Index, to assess the effectiveness of government expenditure on education it is advisable to use real GDP per capita, which measures economic activity and is also used as a proxy for development in a country's material living standards. The indicator is used to show the importance of sustained economic growth and high levels of economic productivity for the creation of well-paid quality jobs and the achievement of global prosperity (Educational expenditure statistics). So, in countries with high and medium levels of real GDP per capita, government expenditure on education is $86-93 \%$, but there are exceptions (for example, Romania).

The quality of education can be assessed by using the indicator "average expenditure per pupil/student". This ratio be impacted such factors as shifts in population structures, declining birth rates, reducing school age populations in many countries, and the participation rate of young children in education. As a result 
annual expenditure (from public and private sources) on all educational institutions shows that in Sweden an average of EUR 13020 was spent per pupil/student, in Croatia the average was EUR 2 694, and EUR 1600 in Bulgaria and Romania. The expenditure per pupil was higher in public institutions than in all institutions.

The financial assistance to households or students in the form of scholarships, government loans or allowances depending on student status, level of education (compulsory education is free, while tertiary education might/might not be free) is one of the instruments for financing education and training in the EU. The financial assistance for education and training is provided in two forms: direct assistance in the form of grants and loans and indirect support (benefits, including tax); virtually all EU Member States use at least one type of direct financial assistance (grant or loan) to students with higher education. Only grants are used by: Belgium, Bulgaria, Czech Republic, Estonia, Ireland, Greece, Spain, France, Croatia, Italy, Latvia, Lithuania, Luxembourg, Hungary, Malta, Austria, Portugal, Romania, Slovenia, and Finland. In some Member States, students can apply for both grants and loans.

As a rule, the structure and size of the financial assistance depend on the national organization of education systems; the various methods that are used to fund education systems and to provide welfare support; and other forms of financial aid to encourage students to remain within the education system. In countries with less developed education sector the financial assistance being provided to students so that they may study abroad.

In general, the government expenditure on education is significant in all EU Member States. For households, the cost of education increases as the pupil / student studies at different levels of education - the cost per pupil / student significantly exceeds the cost of education at the primary levels of education. The largest share in the structure of expenditure on education is occupied by the costs of the secondary education system.

An opportunity for people of all ages to develop and share knowledge and experience at institutions and organizations in different countries (both among Member States and between Member States and third countries) has Erasmus+.

The Program, the purpose of which is to investing in education, training, youth and sport in Europe through a single integrated programmer, has a budget of EUR 14.7 billion (2014-2020), and EUR 1.68 billion additionally for funding actions with third countries (partner countries), attracted through the EU external action budget through external instruments such as Development Cooperation Instrument, the European Neighborhoods Instrument, the Partnership Instrument for cooperation with third countries, and the Instrument for Pre-accession Assistance.

In accordance with the principles of efficiency, funds are distributed as follows: 1) $77.5 \%$ for actions in the field of education and training, including: $43.0 \%$ for 
higher education actions, or $33.3 \%$ of the total budget; $22.0 \%$ to actions in vocational education and training, or $17 \%$ of the total budget; $15 \%$ to school education actions, respectively $11.6 \%$ of the total budget; $5.0 \%$ to adult education actions, which is $3.9 \%$ of the total budget; 2) $10.0 \%$ for actions in the field of youth; 3 ) $3.5 \%$ to the student loan guarantee fund; 4) $1.9 \%$ for Jean Monnet actions; 5) $1.8 \%$ for actions in the field of sport; 6) $3.4 \%$ as a contribution to the operational costs of the national agencies; 7) $1.9 \%$ to cover administrative expenses.

In 2014-2020 the programmer is giving millions for people many opportunity of education and raising qualifications. In particular, overall mobility opportunities have been created for more than 4 million people, including around 2 million students in higher education and around 650,000 students in vocational education and training; around 800,000 lecturers, teachers, trainers, education staff and Youth workers took part in the program; more than 500,000 young people have joined youth exchange schemes; around 200,000 students took part in the Master's degree loan guarantee scheme; more than 25,000 students took advantage of the Joint Master Degrees. Strategic partnerships have been established with 125,000 schools, vocational education and training institutions, higher and adult education institutions, youth organizations and enterprises. More than 150 alliances have been established with 1,500 higher education institutions and enterprises, and a partnership has been established between business and vocational education and training institutions to develop industry skills (Erasmus+. Key figures).

In addition, the creation of a single programmer on education, training, youth and sport resulted in significant simplification, rationalization and synergies in the management of the Programmer; digitalization and the introduction of fast-track grant selection procedures provided administration optimization, and improving nonfinancial indicators for all stakeholders.

There is no change to the overall architecture of the programmer in 2021-2027, including the three key actions already established under Erasmus+ (learning mobility of individuals; cooperation for innovation and the exchange of good practices; support for policy reform). However, it is provided that the budget be doubled to EUR 30 billion (Proposal for a REGULATION OF THE EUROPEAN PARLIAMENT AND OF THE COUNCIL establishing 'Erasmus'), including: $28 \%-$ for higher education actions, $17 \%$ - vocational education and training, $13 \%$ - to school education actions, $4 \%$ - for adult education actions.

Thus, Erasmus+ is effective at different levels of education, both for individual employees and youth, and for business and government structures and systems in general. The Program has shown its ability to expand and adapt to new target groups, to constantly improve its mechanisms, and implementation new mechanisms according to conditions. 
Thanks to an integrated approach to the financing of education and training in the 27 EU Member States, in 2019 the percentage of the population aged 30-34 who have successfully completed tertiary studies (e.g. university, higher technical institution, etc.) was $40.3 \%$; it means that the task of the "Europe 2020 Strategy" is over fulfilled by $0.3 \%$. The percentage of women with higher education increased from $23.7 \%$ in 2002 to $45.6 \%$ in 2019 and from $21.4 \%$ to $35.1 \%$ for men.

Highest share of those aged 30-34 with tertiary education in Cyprus (58.8\%), and in Lithuania (57.8\%), Luxembourg (56.2\%), Ireland (55.4\%), and Sweden (52.5\%) and the Netherlands (51.4\%); lowest in Romania (25.8\%) and Italy (27.6\%) (Europe 2020 education indicators in 2019). In all EU Member States, the share of women aged 30 to 34 who have completed tertiary education is higher than the share of men. Belgium, Czechia, Denmark, Estonia, Greece, Spain, Italy, Cyprus, Latvia, Lithuania, Malta, the Netherlands, Austria, Poland, Slovenia, Slovakia, Finland and Sweden have already met or exceeded their 2020 national target for this indicator.

In the current context of an increasingly dynamic labor market and given the challenges of the European and world economy, the European Economic and Social Committee call on EU Member States at both national and regional levels:

1. To increase the government expenditure in lifelong learning, and earmark targeted funding for the continuous upskilling and reskilling of adults and the most vulnerable groups in society; half of the current workforce will need to update their skills within five years in order to adapt to the impact of digital and technological advances, and to survive on the labor market (Lifelong learning requires more substantial public funding).

2. To finance learning in non-formal and informal settings for develop softer skills (critical thinking, teamwork) and character traits (leadership, curiosity) tailored to jobs of the future.

3. To study in more detail the possibilities of introducing Individual Learning Accounts as one way of enabling people of quality education of working age. The opportunities, benefits and risks of Individual Learning Accounts are discussed in the OECD too (OECD, 2019). In the USA, such a training tool is used to provide a flexible and innovative approach to the development of federal employees. The UK Government has tested Individual Learning Accounts and concluded that such a funding scheme expands participation in training and helps to overcome financial barriers of sustainable human capital development (The National Audit Office, 2002).

The results of the empirical studies indicate that the number of points of the Human Capital Index and place in the ranking do not depend on government expenditure on education. This is why government needs to be aware of the importance and potential of such factors as the efficiency of use of funds, financing by other sectors, organizational aspects, etc. Also, since all stakeholders are interested 
in sustainable human capital development, it is necessary to disseminate the information about the role of education and sources of funding of education.

At the same time, it is necessary to take into account the real GDP per capita, the needs of its stakeholders, number of students, scientific potential, financial capacities, interaction activity both at regional and international levels.

According to the findings in this research, in EU Member States all measures and proposals aimed at ensuring respect for the right to quality and inclusive lifelong learning for all, as well as ensuring sustainable the government expenditure of education and training through consultation and partnership. Such experience of financing education for sustainable human capital development is very useful for other countries, including Ukraine.

The Ukrainian experience of public government in education. Ukraine is one of the countries with a high potential of human resources proved by global rankings and at the same time weak positioning of economy (Degtyarova, 2018). In 2018, Ukraine was classified as a country with a lower middle income and middle level of human capital (Ukraine has 0.65 in the range of 1). The general level of population literacy in the age under 15 years was $99.8 \%$; in particular, $82 \%$ of the population has higher education. Budget expenditures for education were 5.32\% of GDP in 2018 (Table 2).

Table 2. Distribution of expenditure on education by sector in Ukraine

\begin{tabular}{|c|c|c|c|c|c|c|c|}
\hline Indicator & 2012 & 2013 & 2014 & 2015 & 2016 & 2017 & 2018 \\
\hline $\begin{array}{c}\text { Expenditure on } \\
\text { education, million } \\
\text { UAH }\end{array}$ & 111180.1 & 115962.9 & 109520.9 & 127120.9 & 139970.5 & 182980.2 & 214000.0 \\
\hline $\begin{array}{c}\text { Government } \\
\text { expenditure, million } \\
\text { UAH }\end{array}$ & 94005.1 & 97753.0 & 93230.3 & 106178.7 & 119501.6 & 161495.4 & 189405.2 \\
\hline $\begin{array}{c}\text { Non-educational } \\
\text { private, million } \\
\text { UAH }\end{array}$ & 17175.0 & 18209.9 & 16290.6 & 20942.2 & 20468.9 & 21484.8 & 24594.8 \\
\hline \multicolumn{1}{|c|}{ Government } \\
expenditure, \% & 84.55 & 84.30 & 85.13 & 83.53 & 85.38 & 88.26 & 88.51 \\
\hline $\begin{array}{c}\text { Non-educational } \\
\text { private, \% }\end{array}$ & 15.45 & 15.70 & 14.87 & 16.47 & 14.62 & 11.74 & 11.49 \\
\hline $\begin{array}{c}\text { Real GDP per } \\
\text { capita, million UAH }\end{array}$ & 1404669 & 1465198 & 1586915 & 1988544 & 2385367 & 2983882 & 3560596 \\
\hline $\begin{array}{c}\text { Expenditure relative } \\
\text { to GDP, \% }\end{array}$ & 7.92 & 7.91 & 6.90 & 6.39 & 5.87 & 6.13 & 6.01 \\
\hline $\begin{array}{c}\text { Government } \\
\text { expenditure relative } \\
\text { to GDP, \% }\end{array}$ & 6.69 & 6.67 & 5.87 & 5.34 & 5.01 & 5.41 & 5.32 \\
\hline
\end{tabular}

Source: Calculated based on Derzhavna sluzhba statystyky Ukrainy 
In Ukraine, education and training is funded by governments, companies and households. But both national and European experts agree that education funding in Ukraine needs to be reformed.

Degtyarova et al assume that the human capital and its potential are not used efficiently for ensuring the economic growth in Ukraine, mostly because of the complicated heritage of "command mode of economic management, a government as a main customer of educational services", inhibiting development of education for the knowledge economy (Degtyarova, 2018).

Today, the key problems in education are:

1. The educational process at vocational and higher educational institutions is out of touch with needs of the labor market and economy overall.

2. Inadequate funding modalities critically low level of public funding for education, and the mechanism of public higher education funding in Ukraine;

3. In Ukraine, a sizable fraction of today's young people may not be employed when they become adults. Even if they find employment, they may not hold jobs where they can use their skills and cognitive abilities to increase their productivity.

One of the tools of human capital development is human capital strategy. The implementation of this strategy implies complex educational reform in Ukraine.

The main directs of educational reform in Ukraine at the national and regional levels are:

1. The balance and alignment right between national reform and local decision making.

2. The government must to empower of the education leaders and support them in their quest to provide quality learning opportunities for young people.

3. The distribution and allocation of state-funded places should be done according to the principles of transparency, balanced and harmonized development; the best universities should get exceptional support and more funding from the government in order to develop world class research universities.

4. Ukraine should "develop a long-term plan for investing in higher education", which means creating a clear vision of higher education funding in Ukraine (Degtyarova, 2018).

5. To promote knowledge partnerships and strengthen links between education, business, research and innovation.

6. To bridge the gap between research and the implementation of its results, the government must to integrate higher education and science of Ukraine into the education and research space of the European Union.

As a result, it will increase the impact of government on economic, technology and cultural development, human capital formation, and solving social problems; and will achieve the goals of education such as holistically developing the human being 
as a personality; shaping values and competences required for successful selfrealization; and raising the people's educational level to for human capital development (Law of Ukraine On Education).

The conducted research has shown that in EU Member States, education and training as training for future professionals, promoting their competitiveness in the labor market, is funded by governments, private entities (mainly companies and households) and international organizations. The cost of education is constantly rising as Europeans understand their role in society and the need for sustainable human capital development.

In EU along with broad economic development, government policies contributed to some countries' progress in human capital. Effective policies included expanding the population coverage of educational services, notably for making school more affordable; and providing the financial assistance to households or students through mechanisms such as scholarships, government loans or allowances depending on student status, level of education (compulsory education is free, while tertiary education might/might not be free) is one of the instruments for financing education and training in the EU.

Strong gains are more likely in countries with strong governments that are able to funding of education, and to maintain commitment to educational reforms, and to attract whole-of-society to educational policymaking.

In addition, new challenges (such as increased use of technology and changes in the nature of work) contribute to the development and financing of lifelong learning, through which employers and workers can successfully respond to market realities. Human capital development and education financing are supported and coordinated by international organizations.

In the context of globalization, the pandemic, the unfolding of financial and economic crises, the growth of public debt, the main challenges in financing education and training in EU Member States is the dilemma of how to: increase / maintain education funding; ensure fair distribution of financial resources; to increase the efficiency of the use of financial resources in the education system; promote human capital development.

Studies on EU's experience enabled to identify the mechanisms of dominant influence governments on sustainable human capital development such as "framework and rules" established by governments - sufficient funding and an effective policy to ensure the quality of education.

In order to financing education and training for sustainable human capital development it is necessary: 
1) At the national level: to improve the training in vocational programs; to optimize of funding for formal, non-formal and informal education; to share the costs between public authorities and private entities as well as, individuals.

2) at the regional level measures may include both to step up the modernization agenda of higher education; and to ensure efficient investment in education and training systems at all levels (pre-school to tertiary); to develop partnerships between the education/training and work, in particular by involving social partners in the planning of education and training provision etc.

\section{References:}

1. A new EU agenda for higher education. Retrieved from: https://www.europarl.europa.eu/RegistreWeb/search/simple.htm?searchLanguages=EN\&relations=DOSSIE R\%23\%23COM(2017)0247\&sortAndOrder=DATE_DOCU_DESC

2. Degtyarova, I., Hryhorash, O., and Chentsov, V. (2018). The mechanism of higher education funding in Ukraine: nationwide and local perspective. Investment Management and Financial Innovations, 15(3), 223236.

3. Derzhavna sluzhba statystyky Ukrainy. (2020). Retrieved from http://www.ukrstat.gov.ua/

4. Education and Vocational Training. Retrieved https://www.europarl.europa.eu/factsheets/en/sheet/139/education-and-vocational-training.

5. Educational expenditure statistics. Retrieved from: https://ec.europa.eu/eurostat/statisticsexplained/index.php?title=Educational_expenditure_statistics\#Overall_educational_expenditure

6. Erasmus+. Key figures. Retrieved from: https://ec.europa.eu/programmes/erasmus-plus/about/keyfigures_en

7. Europe 2020 education indicators in 2019 . The EU has reached its tertiary education target ...only $0.2 \mathrm{pp}$ away from the target for early leavers. Retrieved from: https://ec.europa.eu/eurostat/documents/2995521/10749941/3-22042020-BP-EN.pdf/04c88d0b-17af-cf7e-

7e78-331a67f3fcd5

8. European policy cooperation (ET 2020 framework). The strategic framework for European cooperation in education and training (ET 2020). Retrieved from: https://ec.europa.eu/education/policies/european-policycooperation/et2020-framework_en

9. Eurostat. https://ec.europa.eu/eurostat/web

10.Higher education. Retrieved from: https://www.europarl.europa.eu/factsheets/en/sheet/140/korgharidus

11.Landry, L., \& Neubauer, D. (2016). The role of the government in providing access to higher education: the case of government-sponsored financial aid in the US. Journal of Education and Work, 29(1), 64-76.

12.Lifelong learning requires more substantial public funding. Retrieved from: https://www.eesc.europa.eu/en/news-media/news/lifelong-learning-requires-more-substantial-public-

funding-0

13.OECD (2019), Individual Learning Accounts: Panacea or Pandora's Box?, OECD Publishing, Paris, https://doi.org/10.1787/203b21a8-en

14.Oluwatobi, S. A and Ogunrinola, I. O. (2011) Government Expenditure on Human Capital Development: Implications for Economic Growth in Nigeria. Journal of Sustainable Development, Vol. 4 (No. 3)

15.Ranson, S., \& Tomlinson, J. (2018). The changing government of education. Routledge.

16.Proposal for a REGULATION OF THE EUROPEAN PARLIAMENT AND OF THE COUNCIL establishing 'Erasmus': the Union programme for education, training, youth and sport and repealing Regulation (EU) No 1288/2013. Retrieved from: https://eur-lex.europa.eu/legalcontent/EN/TXT/?uri=COM\%3A2018\%3A367\%3AFIN

17.Regulation (EU) No 1288/2013 of the European Parliament and the Council of 11 December 2013 establishing 'Erasmust': the Union programmer for education, training, youth and sport and repealing Decisions No 1719/2006/EC, No 1720/2006/EC and No 1298/2008/EC (OJ L 347, 20.12.2013, p. 50)

18.The European Pillar of Social Rights in 20 principles. Retrieved from: https://ec.europa.eu/commission/priorities/deeper-and-fairer-economic-and-monetary-union/european-pillarsocial-rights/european-pillar-social-rights-20-principles_en 
19.The National Audit Office (2002), Individual Learning Accounts. Retrieved from: https://www.nao.org.uk/wp-content/uploads/2002/10/01021235es.pdf

20.The UNESCO Institute for Statistics. Education Finance. Retrieved from: http://uis.unesco.org/en/topic/education-finance

21.Tooley James, (2020). Government and Education, the Changing Role of. (2020). Retrieved from: https://www.encyclopedia.com/education/encyclopedias-almanacs-transcripts-and-maps/government-andeducation-changing-role

22.Treaty of Lisbon amending the Treaty on European Union and the Treaty establishing the European Community. $\quad$ Retrieved from: https://eur-lex.europa.eu/legalcontent/EN/TXT/?uri=CELEX\%3A12007L\%2FTXT

23.Friedman, M. (1955). The Role of Government in Education (1955). https://la.utexas.edu/users/hcleaver/330T/350kPEEFriedmanRoleOfGovttable.pdf

24.World Bank. (2019). Human capital Index 2018. Retrieved from https://photius.com/rankings/human_capital_index_country_rankings_2018.html

25.World Bank. 2020. The Human Capital Index 2020 Update : Human Capital in the Time of COVID-19. World Bank, Washington, DC. (C) World Bank. https://openknowledge.worldbank.org/handle/10986/34432 License: CC BY 3.0 IGO. 